Amino Acid Profile Analysis of Red and Green Melinjo Peels Tea - Saragih, dkk Jurnal Pangan dan Agroindustri Vol. 9 No.4: 208-215, Okt 2021

Accepted: 01/12/2020, Reviewed: 15/03/2021, Published: 31/10/2021

\title{
AMINO ACID PROFILE ANALYSIS OF RED AND GREEN MELINJO PEELS TEA
}

\author{
Raskita Saragih ${ }^{1}$, Ermiziar Tamizi $^{2}$, Shinta Leonita ${ }^{1 *}$ \\ 1) Department of Agroindustrial Technology, Institut Teknologi Indonesia \\ 2) Department of Chemical Engineering, Institut Teknologi Indonesia, \\ ${ }^{*}$ Correspondence Author, Email: shinta.leonita@iti.ac.id
}

\begin{abstract}
The study aims to analyze the profile of non-essential and essential amino acids in the peels and herbal tea products made from red and green melinjo peels. The processing of melinjo seeds into chips in Pandeglang Regency in Banten Provence, produces large amounts of melinjo peels waste. The processed tea from red and green melinjo peels contains polyphenol compounds, antioxidants, protein and amino acids that are good for health. The processing stages of the melinjo peel tea by sorting the peels for red and green melinjo peels, then washed, made them into thin slices, and dried using an oven blower at $65^{\circ} \mathrm{C}$ of temperature for 4 hours. Both green and red melinjo peels tea were analyzed for the amino acid profile using the UPLC method. Based on the results of the analysis, it was found that the amino acid content of melinjo peels and melinjo peels tea, both green and red, consisted of 7 non-essential amino acids and 8 essential amino acids. L-glutamic acid and L-aspartic acid are the highest amino acid components which can give melinjo peels tea a characteristic aroma and taste.
\end{abstract}

Keywords: Amino acids, Melinjo peel, Tea, UPLC

\section{INTRODUCTION}

Banten province has a relatively large industrial center for melinjo emping in Indonesia. Department of Industry has set melinjo emping as typical food of Pandeglang and recorded that the production reached 156 tons per month or 5.2 tons per day on average in Pandeglang Regency (Kemenperin.go.id., 2019). According to the Badan Pusat Statistik Provinsi Banten (2020), melinjo production in this province made 54529.2 tons per year. This high amount certainly leads to abundant fruit peel waste every year. However, it can be beneficial through processing into a product that has an economic value such as herbal tea. The melinjo peel processing into herbal tea is useful to elevate public welfare and economy and it can enrich the variety of a drink.

The phytochemical components contained in melinjo peels bring about the green, yellow, and red color of melinjo peels. Known widely the various uses of phytochemical components i.e., carotenoids, phenolics, and flavonoids, one of them is as an antioxidant which significantly important for health.

The protein quality of food is determined by the amino acid level content. Amino acids fall into 2 groups, namely non-essential and essential amino acids. Human body cannot synthesize the essential amino acid. Moreover, an organism approximately needs 33 kinds supplementary amino acids of foods consumed to meet its protein intake. However, the nonessential amino acids can be provided by human body through a complicated biosynthesis process from nitrogen compounds found in foods (Anwar, 2017).

The tea product of red and green melinjo peel preferred by panelists has been analyzed for their antioxidant and polyphenols (Saragih, R. et al., 2018). Further research is certainly needed to find out both non-essential and essential amino acids contained in the peel and red and green melinjo peel tea that was preferred. 


\section{METHODOLOGY}

\section{Materials}

The raw materials used were red and green melinjo peels obtained from vegetable sellers in Serpong Market Tangerang, which also came from all over Banten.

\section{Tool}

This research utilized the processing tools consisting of washbowls, water filter, stove, digital scale, pan, stainless steel knife, cutting board, trays, scissors, plastic valve bags, labels, oven blowers, and rags. Moreover, the analysis tool for the amino acid profile was UPLC (185-17/MU/SMM-SIG).

\section{Research Design}

The research is carried out by descriptive-qualitative design on the research data, and observations during the research.

\section{Research Stages}

The materials prepared were melinjo peel, and red and green melinjo peels tea, each of them was $500 \mathrm{~g}$. The next step is cleaning from the dirt stuck by washing with liquid soap and running water. Afterwards the melinjo peels were sorted by physical damage and then wither it with hot water at temperature of $70^{\circ} \mathrm{C}$ for $2-3$ minutes, drain until sufficiently dry, cut thinly to $\pm 2 \mathrm{~mm}$ wide until it weighs to $50 \mathrm{gr}$, dry at $65^{\circ} \mathrm{C}$ for 4 hours, brew with hot water $\left(80^{\circ} \mathrm{C}\right)$ for 4 minutes. The last step is to analyze the amino acid profile using UPLC method. The processing stages of the melinjo peel tea were based on the previous research by Saragih, R. et al., (2018). The research stages can be seen in Figure 1.

\section{Method}

The analysis method of amino acid components was carried out in the PT. Saraswanti Indo Genetech Laboratory using UPLC (18-5-17/MU/SMM-SIG) method.

\section{Analysis Procedure}

The data analysis used the descriptive method. Once the data analysis obtained, the amino acid components of melinjo peels and red and green melinjo peels tea was then analyzed. 


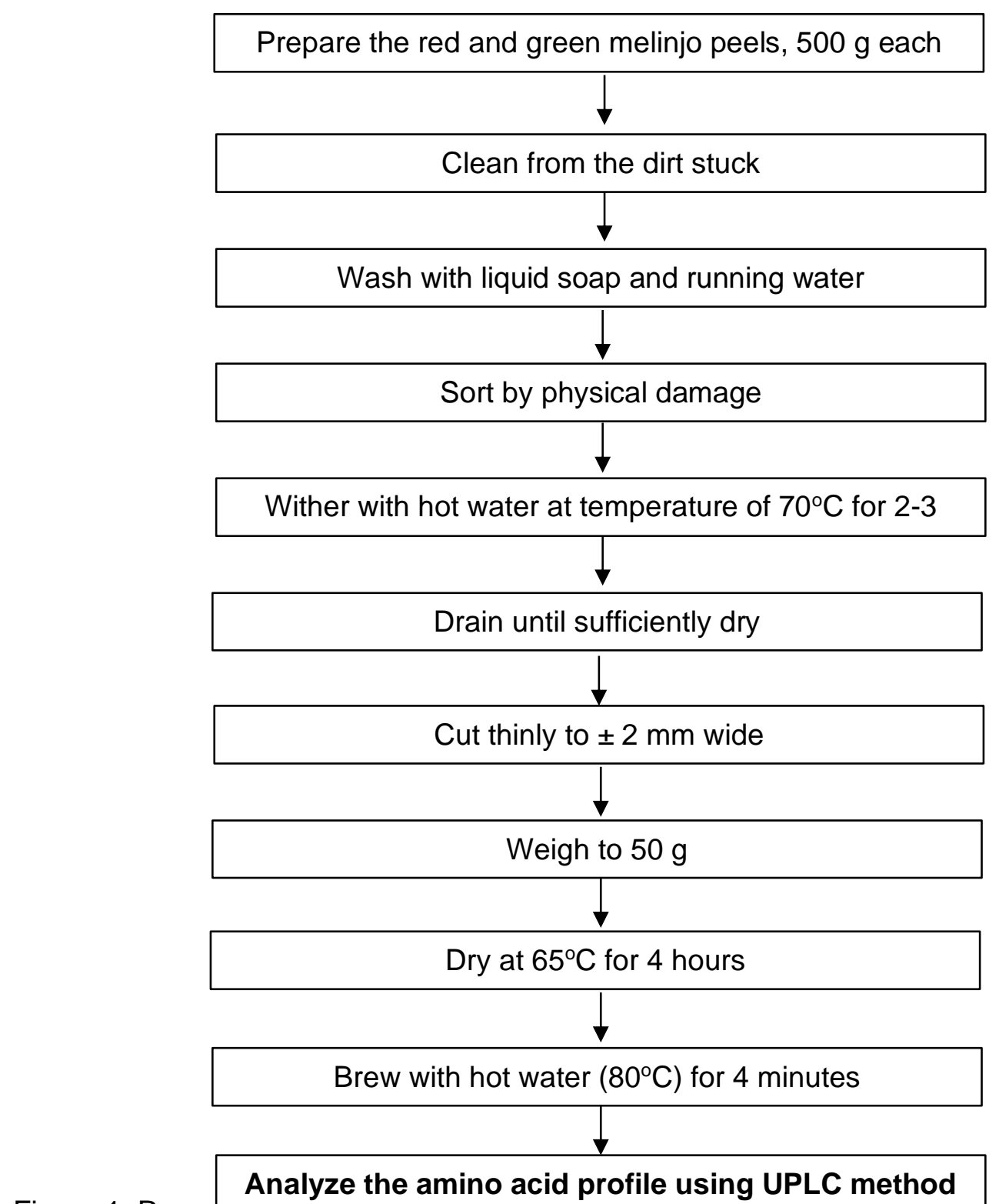

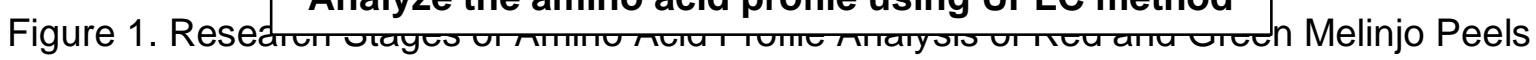
Tea

\section{RESULTS AND DISCUSSION}

The sample preparation carried out in the research included cutting the melinjo peels, then drying them at $65^{\circ} \mathrm{C}$ for 4 hours. And, the brewed green and red melinjo peels tea obtained are presented in Figure 2 and Figure 3.

The amino acid component analysis aims to know the chemical composition percentage of melinjo peel, and red and green melinjo peels tea. Moreover, it was carried out using Ultra High Performance Liquid Chromatography (UPLC), an instrument used to determine amino acid content with higher efficiency than a conventional HPLC such as the more efficient analysis time, number of samples and required mobile phase, sensitivity, and cost (Bi et al., 2016) (Annisa et al., 2019). 


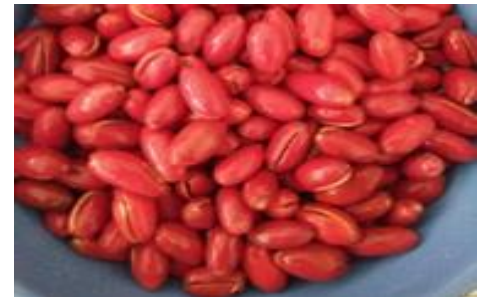

(a)

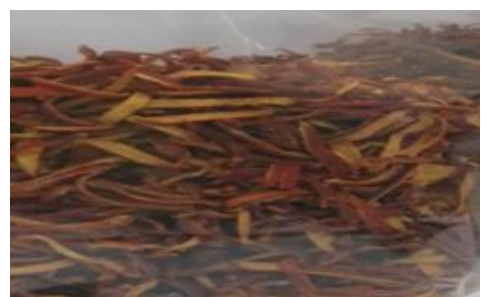

(b)

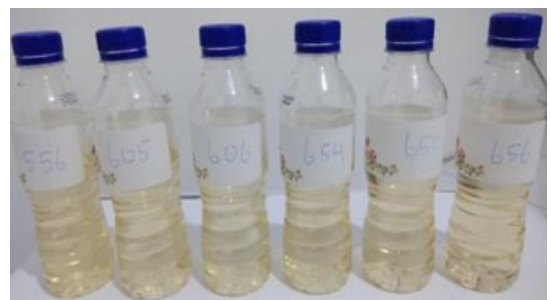

(c)

Figure 2. Melinjo Peels (a), Melinjo Peels after Drying (b) and the Brewed Melinjo Peel Tea (c) Red Color

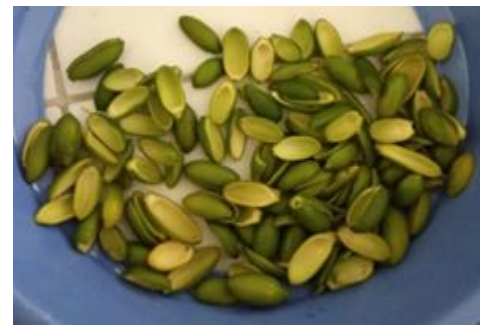

(a)

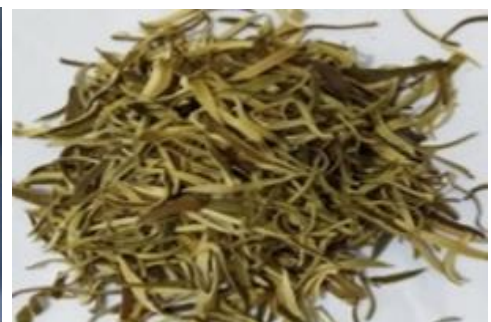

(b)

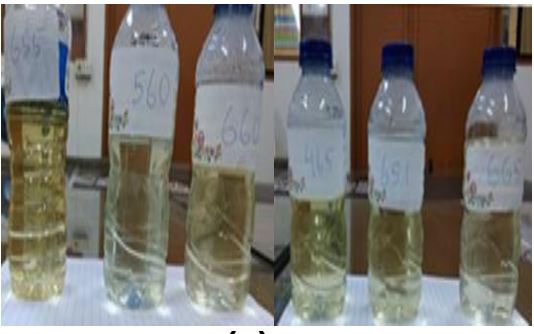

(c)

Figure 3. Melinjo Peel (a), Melinjo Peel after Drying (b) the Brewed Melinjo Peel Tea (c) Green Color

The results of amino acid analysis of melinjo peel and red and green melinjo peels tea are presented in Table 1.

Table 1. The Acid Amino Component of Melinjo Peel and Red And Green Melinjo Peels Tea

\begin{tabular}{clcccc}
\hline No & Amino Acid & $\begin{array}{c}\text { Green } \\
\text { Melinjo } \\
\text { Peel (\%) }\end{array}$ & $\begin{array}{c}\text { Green Melinjo } \\
\text { Peel Tea (\%) }\end{array}$ & $\begin{array}{c}\text { Red } \\
\text { Melinjo } \\
\text { Peel (\%) }\end{array}$ & $\begin{array}{c}\text { Red Melinjo Peel } \\
\text { Tea (\%) }\end{array}$ \\
\hline 1 & L-Serine & 0.132 & 0.851 & 0.220 & 0.692 \\
2 & L-Glutamic Acid & 0.281 & 1.889 & 0.486 & 1.632 \\
3 & L-Phenylalanine & 0.096 & 1.089 & 0.172 & 0.586 \\
4 & L-Isoleucine & 0.107 & 0.752 & 0.182 & 0.602 \\
5 & L-Valine & 0.159 & 1.192 & 0.300 & 0.934 \\
6 & L-Alanine & 0.117 & 0.865 & 0.296 & 0.839 \\
7 & L-Arginine & 0.098 & 1.232 & 0.098 & 0.614 \\
8 & Glycine & 0.153 & 1.146 & 0.251 & 0.798 \\
9 & L-Lysine & 0.123 & 0.735 & 0.224 & 0.502 \\
10 & L-Aspartic Acid & 0.207 & 1.709 & 0.406 & 1.190 \\
11 & L-Leucine & 0.144 & 1.012 & 0.256 & 0.832 \\
12 & L-Tyrosine & 0.104 & 1.026 & 0.158 & 0.600 \\
13 & L-Prolin & 0.108 & 0.729 & 0.212 & 0.622 \\
14 & L-Threonine & 0.124 & 0.904 & 0.215 & 0.660 \\
15 & L-Histidine & 0.080 & 0.521 & 0.074 & 0.282 \\
\hline
\end{tabular}

Based on the result of amino acid analysis of melinjo peel and melinjo peel tea both red and green, 15 types of amino acid were obtained, namely 7 non-essential amino acids and 8 essential amino acids. The non-essential amino acids found in melinjo peel and red and green melinjo peel tea are L-glutamic acid, L-aspartic acid, glycine, L-serine, L-proline, Lalanine, L-tyrosine, while in essential amino acids are L-arginine, L-valine, L-leucine, Lthreonine, $\mathrm{L}$-phenylalanine, L-isoleucine, L-lysine, L-histidine. Furthermore, the essential and 
non-essential amino acid level histogram of melinjo peel and red and green melinjo peel tea presented in Figure 4 and Figure 5.

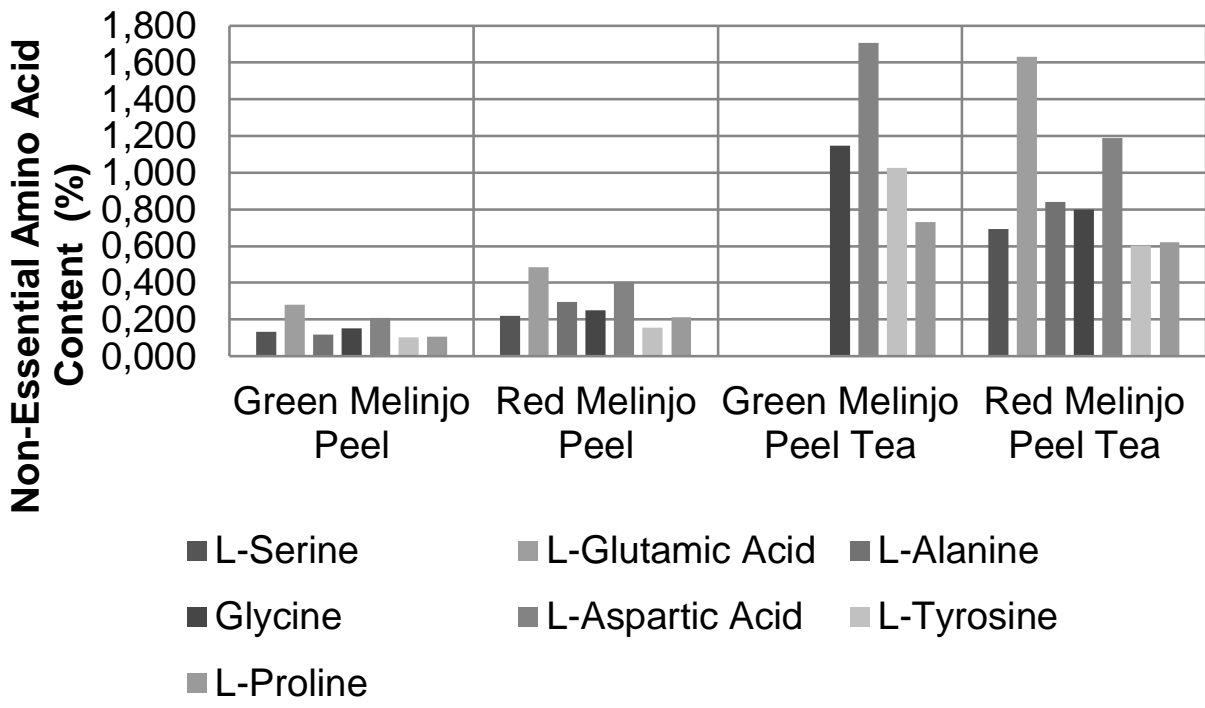

Figure 4. A Histogram of Non-essential Amino Acid of Melinjo Peel and Red and Green Melinjo Peels Tea

The highest amino acid content was L-glutamic acid. The L-glutamic acid content of the green melinjo peel is $0.281 \%$ and in the processed product of the green melinjo peel tea is $1.889 \%$. Furthermore, the L-glutamic acid content of the red melinjo peel is $0.486 \%$ and it increased to $1.632 \%$ after it became a tea product. A research reports L-aspartic acid, Lglutamic acid, L-theanine and L-arginine are the dominant amino acids in the brewed green tea leaves of several species types of Camellia, C. japonica, and C. sasanqua, where the amino acid contributed to the aroma and flavor of a food (umami or savory), and have relaxing effect which can reduce stress. Glutamic acid can stimulate the nerves in the human sense of taste (Sulistyowibowo et al., 2013). Based on the L-theanine metabolism pathways found in green leaves, they have chemical structures $y$-etil amino-L-glutamat acid synthesized within the root and transported to sprouting a shoot. It, then, is hydrolyzed into glutamic acid and ethyl amine by an enzyme. The glutamic acid is then used to produce aspartic acid and alanine under aerobic conditions and converted into $\gamma$-aminobutirik (GABA) acid in anaerobic condition. Whereas, ethil amine is degraded into acetaldehyde, and it is so with hydrogen peroxide into ammonia which is released as nitrogen source and widely used in the synthesis of various amino acids, especially threonine and glycine (Syah \& Djayeng, 2005).

L-aspartic acid is the second highest non-essential amino acid. The L-aspartic acids of the green melinjo peel is $0.207 \%$ and for the green melinjo peel tea increased to $1.709 \%$. Whereas, L-aspartic acid content of red melinjo peel is $0.406 \%$ and increased to $1.190 \%$ when it has become processed product of red melinjo peel tea. Bi et al., (2016) reported amino acid contents of 199 tea product samples from 33 plant species, except non-Camellia tea, were 20 free amino acids consisting of 3 non-essential amino acids i.e., aspartic acid, serine, alanine; 9 essential amino acids such as phenylalanine, isoleucine, valine, methionine, lysine, leucine, tryptophan, threonine, and histidine; 6 conditional essential amino acid namely, glutamine, glycine, arginine, cysteine, proline, and tyrosine; and 2 active amino acids, that is, Thea and Gamma aminobutyric acid (GABA). Total amino acid in tea product samples of non-Camellia plants is lower than the Camellia tea. However, the total content of certain amino acid is higher, such as the aspartic acid content of Rosela (Hibiscus sabdariffa L.) is $2.61 \mathrm{mg} / \mathrm{g}$ and Jiaogulan (Gynostemma pentaphyllum) is $2.75 \mathrm{mg} / \mathrm{g}$ higher than Green tea is $1.24 \mathrm{mg} / \mathrm{g}$. It proved that the aspartic acid content of the green melinjo peel tea $(17.08885 \mathrm{mg} / \mathrm{g})$ and the red melinjo peel tea $(11.89587 \mathrm{mg} / \mathrm{g})$ is higher than green tea. 


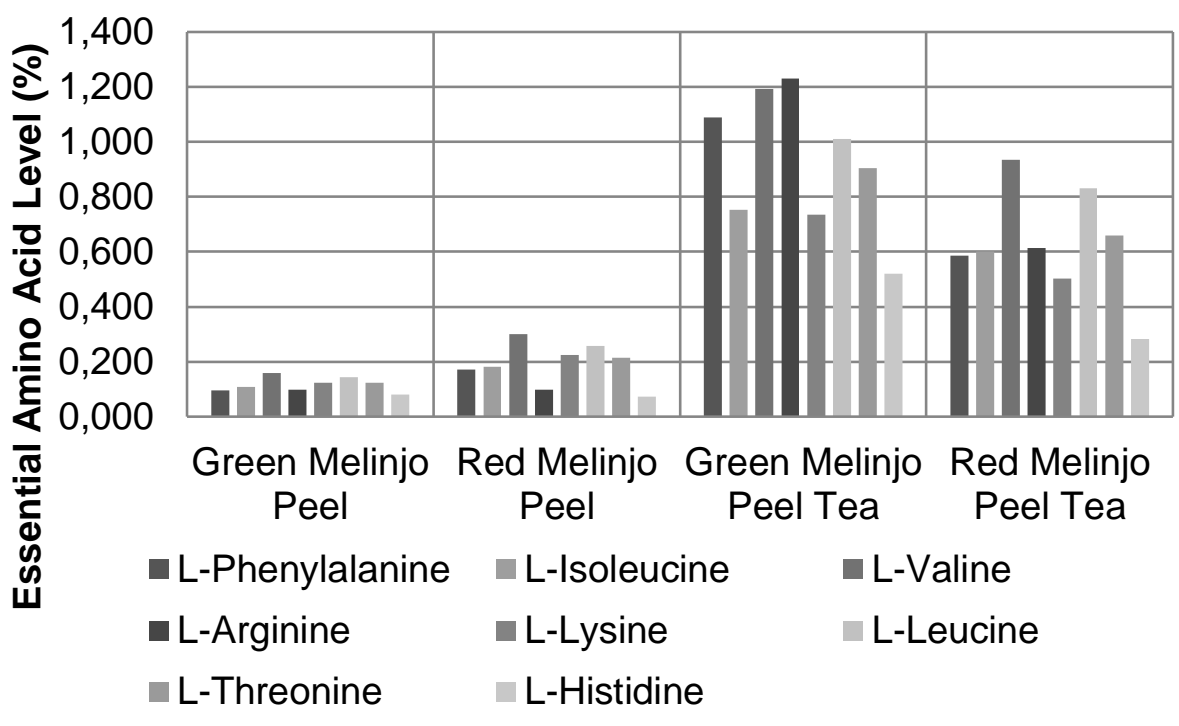

Figure 5. A Histogram of Essential Amino Acid of Melinjo Peel and Red and Green Melinjo Peel tea

L-arginine (1.232\%), L-valine (1.192\%), L-leucine (1.026\%), and L-Threonine (0.904\%) are the highest essential amino acids that play dominantly in the green melinjo peels. The following advantages of L-arginine can increase; body endurance and production of growth hormone, and has a significant role in the blood vessel, can be a potential neuroprotective agent, and act as an immunomodulator and cytotoxic against free radicals (Linder, 2006)(Utami \& Zafrullah, 2019)(Appleton, 2002). Furthermore, L-valine functions as glucogenic precursors, essential for growth, maintains muscle tissue, boosts mental abilities, promotes muscle coordination, helps to repair damaged tissue and maintains nitrogen balance (Anwar, 2017). L-Leucine is mostly found in protein food sources that maintain the immune system (Sulistyowibowo et al., 2013). L-Threonine has functions to keep the protein balance in the body, elevate intestinal ability and digestive process, help build collagen and elastin, help the liver, heart, and central nervous system function and prevent epileptic seizures (Anwar, 2017).

Both green and red melinjo peels increased in their amino acid concentration after being processed into tea products. It is also related to the melinjo peel tea processing. According to Saragih, R. et al., 2018), melinjo peel tea processing was through the following phases: raw material sorting, a withering process using hot water at $70^{\circ} \mathrm{C}$ temperature for $2-3$ minutes, raw material downsizing and drying process at $65^{\circ} \mathrm{C}$ temperature for 4 hours using oven blower. The chemical changes i.e. enzyme inactivation and the protein breakdown into free amino acids such as phenylalanine, leucine, alanine, valine, and isoleucine happened during the withering process (Anjarsari, I, R, 2016) (Juniaty, 2013). Moreover, the process also caused water content reduction but made the protein level change reversely. According to Purwaningsih et al (2013) the heat used in the foodstuffs processing can reduce water level percentage which causes the increase of protein level percentage. The increase in protein level after processing into tea products also correlates with the increase of its amino acid levels. This melinjo peels processing into tea products definitely can develop local food as a functional drink source of amino acids, both non-essential and essential amino acids.

\section{CONCLUSIONS}

Both red and green melinjo peel and melinjo peel tea contained of 7 non-essential amino acids and 8 essential amino acids. The non-essential amino acids content in both red and green melinjo peel and melinjo peel tea namely L-glutamic acid, L-aspartic acid, glycine, 
L-serine, L-proline, L-alanine, L-tyrosine, and the essential amino acids are L-arginine, Lphenylalanine, L-leucine, L-valine, L-threonine, L-isoleucine, L-lysine, L-histidine. Moreover, L-glutamic acid and L-aspartic acid are dominant as the highest non-essential amino acid. The green melinjo peel contained L-glutamic acid $(0.281 \%)$ and L-aspartic acid $(0.207 \%)$, the processed product of the green melinjo peel, furthermore, increased into L-glutamic acid $(1.889 \%)$ and L-aspartic acid (1.709\%). And, for the red melinjo peel contained L-glutamic acid $(0.486 \%)$ and $\mathrm{L}$-aspartic acid $(0.406 \%)$, whereas, the red melinjo peel tea increased into L-glutamic acid (1.632\%) and L-aspartic acid (1.190\%). The highest essential amino acids in the green melinjo peel tea are dominated by L-arginine (1.232\%), L-valine (1.192\%), L-leucine $(1.026 \%)$ and $L-T h r e o n i n(0.904 \%)$. The glutamic acids contained in the peel and melinjo peel tea play an essential role in giving the tea its distinctive taste.

\section{ACKNOWLEDGMENT}

We would like to thank the Center for the Research and Community Service (PRPM) ITI for the financial support. Also, we thank the Agroindustrial Technology Study Program and Chemical Engineering Study Program of the Indonesian Institute of Technology, for the laboratory facilities provided. Special thanks to the following students, Nandar, Giggario, and Ezra for the sincere assistance to the research.

\section{REFERENCES}

Anjarsari, I, R, D. (2016). Katekin teh Indonesia: prospek dan manfaatnya. Kultivasi, 15(2). https://doi.org/10.24198/kultivasi.v15i2.11871

Annisa, S., Ida, M., \& Lina, I. (2019). Perbandingan Metode Analisis Instrumen HPLC dan UHPLC : Article Review. Jurnal Farmaka, 17(3), 189-197.

Anwar, N. (2017). Sumber Pangan Baru Melalui Pengolahan Kulit Kering Ikan Hiu dan Pari di Indonesia. In Prosiding Seminar Nasional Kelautan dan Perikanan (pp. 65-75). Jakarta.

Appleton, J. (2002). Arginine: Clinical potential of a semi-essential amino acid.. Alternative Medicine Review: A Journal of Clinical Therapeutic, 7(6), 512-522. http://www.ncbi.nlm.nih.gov/pubmed/12495375

Badan Pusat Statistik Provinsi Banten. (2020). Tanaman Holtikultura di Provinsi Banten 2019. BPS Provinsi Banten. Serang.

Bi, W., He, C., Ma, Y., Shen, J., Zhang, L. H., Peng, Y., \& Xiao, P. (2016). Investigation of free amino acid, total phenolics, antioxidant activity and purine alkaloids to assess the health properties of non-Camellia tea. Acta Pharmaceutica Sinica B, 6(2), 170-181. https://doi.org/10.1016/j.apsb.2015.11.003

Juniaty, T. (2013). Kandungan Senyawa Kimia Pada Daun Teh (Camellia sinensis). Warta Penelitian Dan Pengembangan Tanaman Industri, 19(3), 12-16.

Kemenperin.go.id. (2019). Depperin Tetapkan Emping Melinjo Makanan Khas Pandeglang. https://kemenperin.go.id/artikel/1608/Depperin-Tetapkan-Emping-Melinjo-MakananKhas-Pandeglang

Linder, M. (2006). Nutrional Biochemistry and Metabolism. UI Press. Jakarta.

Purwaningsih, S., Salamah, E., \& Apriyana, G. P. (2013). PROFIL PROTEIN DAN ASAM AMINO KEONG IPONG-IPONG (Fasciolaria salmo) PADA PENGOLAHAN YANG BERBEDA. Jurnal Gizi Dan Pangan, 8(1), 77. https://doi.org/10.25182/jgp.2013.8.1.7782

Saragih, R., Giggario, H. Y., Ermiziar, T., Yuli, A. H., \& Latifa, H. (2018). Karakteristik Teh Kulit Melinjo Warna Merah dan Hijau. Prosiding Technopex ITI, 352-358.

Sulistyowibowo, W., Titin, A. Z., Nora, I., \& Warsidah. (2013). Analisis Asam Amino dan Mineral Essensial pada Ubur-Ubur (Aurelia aurita). Jurnal Kimia Khatulistiwa, 2(2), 101106.

Syah, A. N. A., \& Djayeng, S. (2005). L-Theanin: Asam amino unik dari daun Teh Hijau. Prosiding Seminar Nasional Teknologi Inovatif Pascapanen Untuk Pengembangan 
Amino Acid Profile Analysis of Red and Green Melinjo Peels Tea - Saragih, dkk Jurnal Pangan dan Agroindustri Vol. 9 No.4: 208-215, Okt 2021

Industri Berbasis Pertanian, 679-687.

Utami, N. A., \& Zafrullah, K. J. (2019). L-Arginin, suatu peluang Neuroproteksi terhadap pasie Preeklampsia yang Mendapat Problem Neurologis. Jurnal Neuroanestesi Indonesia, $8(2), 144-152$. 